\title{
Augustine's Approach to Heresies as an Aid to Understanding His Ideas on Interaction between Christian Traditions
}

\author{
PaulJ.J. van Geest
}

Few thinkers can rival Augustine's (354-430) influence on Western anthropology, theology, and cosmology (Pollmann, Otten et al. 2013). After his baptism in Milan in 387 he developed into an extraordinarily prolific writer. He wrote a great number of sermons, letters, biblical commentaries, and longer works in which he emphasised the primacy of grace, arguing that this preceded good will. He also composed treatises in which he attempted to safeguard the unity of the church, for instance by accusing the Donatists of seriously wounding the church as the Body of Christ through their schism, as we shall see below. His examination of conscience and the self-analysis performed in his Confessiones, as well as his account of history and of the ideal social- and societal order in De ciuitate Dei, composed to prove the value of Christianity, have been most influential throughout the centuries. But at the end of his life, Augustine had to leave four works unfinished. One of these was his Retractationes (426-427): the catalogue of his works in chronological order, each accompanied by criticisms, corrections, and comments. It was intended as a toolbox for the expansion and spread of Latin Christendom (Drecoll 2001: 330-334). A second unfinished work was his Speculum (427): an anthology of commandments and prohibitions from the Old and New Testaments intended to confront its readers - without engaging in too many hermeneutical feats - with the right way of living (Van Geest 2017, 2018). ${ }^{1}$ But the second book of the Speculum, announced in the praefatio, remained unwritten. The Pelagian Julian of Aeclanum, who strongly emphasised the goodness of human nature, and God's grace to a much lesser degree, demanded all his attention. The resulting book

1 Cf. Possidius, Vita Augustini 28; Ponzio-Vita di Cipriano. Paolino-Vita di Ambrogio. Possidio-Vita di Agostino. Introduzione, traduzione e note a cura di M. Simonetti. Roma, 2000 (third edition); Augustinus, Speculum, Praefatio (ed. Weihrich), Wien: 1887, 1-13 (Corpus Scriptorum Ecclesiasticorum Latinorum 12). 
Contra Iulianum similarly remained an opus imperfectum. The fourth work to remain unfinished was De Haeresibus ad Quodvultdeum (428). Augustine had been planning to address the question as to what makes someone a heretic in the second part of De Haeresibus; but this part was never written.

The first part of De Haeresibus contains an overview, as lucid as it is succinct, of known and unknown heretical factions. This gives the work special value, as it affords us a glimpse of the increasingly globalised and yet somehow interconnected Christianity of his day, of the multi-dogmatic plurality of Christian communities and their leaders, as well as of his awareness of these facts (Brown, Doody and Paffenroth 2008). ${ }^{2}$

Desirous as he was of building and maintaining the unity of the Catholic church, Augustine from an early stage occupied himself with the question how to determine who is a heretic (for terminology: Kaufhold 2011: 313-316). For him, persistence in error-the evidence of pride-made the heretic. And heresy was error in relation to the teaching of the apostles, the catholica ueritas, the Christian concept of God, the incarnation of the Son, the Trinity, or the resurrection of the body (Wurst 2010). But what was Augustine's objective in listing these groups within Christianity in De Haeresibus? Why did he reject the normativity of interpretations of the tradition as detrimental to the unity of the church? Was he interested only in denouncing dogmatic plurality in listing 'suspect' Christian communities?

As a study of De Haeresibus alone would produce a one-sided and static picture of how Augustine evaluates the multi-dogmatic plurality of Christian communities, it is useful to look at the four phases in the development that he underwent in his dealings with the Donatists. It is true that the first heresy Augustine fought was that of the Manicheans. He wrote his tracts against the Manicheans much earlier than against the Donatists. His treatment of the Manicheans was completely different. In his eyes their doctrine was completely false; the followers deserved punitive measures. He did not invite them to come back to the Catholic Church. There is little development in his vision of the Manicheans. That is why the Donatists and not the Manicheans are discussed in this article. Apart from the fact that this development implicates a certain dynamic understanding of what a heresy might be, it turns out that his view of 'heretics' was also very varied and sometimes even positive. This is evident moreover from a 'snapshot' contained in Enarratio in Psalmum 9 and Sermo 117 respectively. Before we examine De Haeresibus and after we have

2 Augustine's thought is examined for how it can inform modern inter-religious dialogue. The premise is that he "can remind us on ways and perspectives that we might be lacking or overlooking” (Brown, Doody and Paffenroth 2008: vii). 
analysed the stages in Augustine's development vis a vis heretics we will study this Enarratio and Sermo.

\section{Augustine's Relations with Specific Heretics: Four Stages in His Development}

The Donatists in North Africa legitimated their existence by emphasising that they were the descendants of Christians who had refused to give the sacred scriptures of Christianity up for destruction during the persecution under the Emperor Diocletian, despite the latter's orders to do so in $303 .{ }^{3}$ Although it was already uncertain around 310 , a few years after the persecution, who had and who had not collaborated with the government, the Donatists regarded Catholics as traditores: squanderers of the books. ${ }^{4}$ They condemned the consecration of Caecilian, elected the new primate of Africa in Carthage in 311 or 312 , because one of the consecrating bishops was suspected of being a traditor. Caecilian was able to retain his position because he enjoyed the support of the Emperor Constantine, whose objective was to create a single universal church in the whole world. But the Numidian bishops elected Majorinus as primate. His successor Donatus was a charismatic man, who from 313 onwards succeeded in forming large groups of Africans into an alternative to the Catholic Church in Numidia.

As Augustine regarded the Catholic Church as the guardian of the unity and wholeness of the church as the Body of Christ, he condemned the development in which one single regional interpretation of Christianity declared itself to be the norm. As early as 391, therefore, Augustine deemed the Donatist Church to be too much a regional phenomenon to be able to be the guarantor of the unity of the universal church. He therefore called on the Donatists to re-join the Catholic Church, all the more stringently as he believed that unity with Christ was preserved exclusively through and in the Catholic, i.e. global church: for him this was the body of Christ which could not be violated through the amputation of parts. ${ }^{5}$ Themselves mainly members of the regional establishment, many Donatists viewed Catholic (and imperial) universalism

3 For a general overview of the issues concerning the Donatists see: Lancel and Alexander 1999a; Lancel 1999b: 232-248, 388-429; Smither 2015; Müller 2011:178-189.

4 Cf. Acta Martyrum Saturnini Presbyteri, Felicis, Dativi, Ampelii et Aliorum, in: col. 688-703, J.-P. Migne (ed), Patrologia Latina 8 (Paris, 1844), especially col. 690.

5 Cf. Enarratio in Psalmum XCIV, 8, in: E. Dekker and J. Fraipont, eds (1990) Enarrationes in Psalmos LI-C (2nd edition): Brepols: Turnhout: 1337-1338 (Corpus Christianorum Series Latina 38 . 
with distaste. They based themselves on Scriptural passages which Cyprian and Tertullian had used during the times of persecution to keep the Christians together, describing the church as a hortus conclusus, fons signatus (a garden enclosed, a fountain sealed up), an exclusive place because it exclusively contained the fountain of grace (Lancel and Alexander 1999a: 625-628). ${ }^{6}$

Previous publications have charted the development that Augustine underwent in his dealings with the Donatists (Van Geest 2015: 289-309; Van Geest 2014: 151-184). His work from the period up to 397 shows that his primary pursuit was peaceful dialogue with them; a dialogue for which he drew up twelve rules. Thus between 391-395 he wrote to Maximinus, the Donatist bishop of Sinitum, that (1) the dialogue must not be troubled by the raking up of memories of the violence perpetrated by Catholics and Donatists alike; (2) it must be conducted openly and (3) everyone must be appraised of the contents of the respective bishops' letters (Epistula 23.6). In addition (4) it is important that all parties know that they are equal; no one from either party must regard himself as morally better than the other (Epistula 23.6; see also Epistula 35.1). And finally, Augustine at this time rejected enforcing dialogue by using or threatening to use state intervention (cf. Retractationes 2.5). In Epistula 33, he also added (6) that the dialogue must be based on mercy and the interlocutor may choose the first subject of conversation (Epistula 33.6). He even proposed to the Donatist bishop Proculeianus that the latter (7) could draw up the rules of the dialogue, (8) take a colleague with him, and even (9) that Augustine would not personally engage in the talks, but that the unschooled Catholic bishop Samcucius would be his interlocutor (Epistula 34.5-6, 10). He wanted nothing to stand in the way of this dialogue. Finally, he proposed in Epistula 44 to a group of Donatist laymen that the dialogue (10) should take place in a calm and neutral village where neither party had a church, (11) that the canonical books and the documents that both parties had at their disposal should be brought along, and (12) that the dialogue should take all the time that might be needed (Epistula 44.14).

There is no mistake that up to 399, Augustine favoured dialogue with partes in non-Catholic Christendom, but the purpose of this exercise was to bring them into Catholic unity. But as soon as it became evident after 399 that his strategy was not working, he changed his view.

First he declared in Epistula $5^{1}$ (399-400) to the Donatist bishop Crispinus that he would accept state intervention in the Donatist controversy, although he refrained from giving the state full scope to punish (Epistula 51.3). Although

6 Cf. J. Alexander, S. Lancel, 'Donatistae', in: A. Mayer (ed.), K.-H. Chelius, A. Grote (red.), Augustinus-Lexikon. Basel, 1986-... Dl. 2, fasc. 3/ 4 (Basel 1999), kol. 6o6-638, esp. 625-628. 
he mentioned this drastic measure in his Ad catholicos fratres (401-402), his tone remained mild. He accused the Donatists of causing schism (crimen schismatis), which had rent the unity of the universal church (Ad catholicos fratres 6 , 7, 35 and passim). But he refused to brand them heretics (haeretici), calling them 'only' schismatics. This is important, because it implies that Augustine did not wish Constantine's anti-heretical laws to be applied to them, thus preventing that they would be regarded as enemies of the state (Ad catholicos fratres 7).

Second, in the period from 399 to 405 his tone changed. The letters he wrote in this period show that he wanted to subject his opponents to sharp interrogation, as he was used to do in his capacity as judge (Raikas 1997; Pugliese 2009). This was a clear breach of his own rules for dialogue. Thus Epistula 76 from 403 , addressed to the Donatists in general, contains a barrage of questions (Contra Cresconium 2.3.4). Similarly, he acknowledged to the Donatist Cresconius at this time that the Donatists had not deviated from the orthodox teachings of the church and that they had the sacraments (Contra Cresconium 2.3.4). But he added a new element to his definition of 'heresy': the Donatists could nevertheless be called heretics because they persisted in their schism: "Heresy is inveterate schism" (Contra Cresconium 2.7.9; Contra Cresconium 2.8.10). ${ }^{7}$ It appears that by 405 he was happy to see the Donatists treated in precisely the same way as the Manichaeans: as heretics for whom, pursuant to imperial laws, much stricter punishments were in order.

But this period of tougher attitudes did not last long. Between 405 and 411 Augustine wrote to the Donatist bishop Emeritus that the lack of that moderation (moderatio) which is akin to mildness in the mutual dealings of Christians pained him (Epistula 87.8.). But he did write this at a time when he was able to rely on the execution of the Emperor Honorius's laws prescribing state intervention to combat heretics in order to safeguard the unity of the church. Although he did not abandon the idea that the Donatist schism had become heresy because the Donatists persevered in it, he again called them schismatics, thus softening his rhetoric (Epistula 87.1-2; 87.4; 87. 6; 87.7; 87.8.). In personal correspondence after 405, it is clear that Augustine was keen to position himself as a teacher rather than as a judge. He became a teacher who explains, rather than interrogates, why the unity of the church must not be broken. This is evident for instance from Epistula 105 to the Donatists, written around 406. In this letter he explained why the love of Christ is effective only within Christ's body, the church (Epistula 105.17). This text also shows that he

7 Contra Cresconium 2.7.9: "haeresis autem, schisma inveteratum"; Contra Cresconium 2.8.10: "nam et haeretici estis, vel quod in schismate inveterato remansistis". 
was convinced at this point that formation must necessary follow compulsion. His long lesson on this subject once again culminated in an entreaty which passionately invited the Donatists to love peace and unity. All this was entirely in accordance with the guidelines he gave himself in Epistula 93.1.3 (407-408): coercion must go hand in hand with, and must be followed by, education and formation. If not, it turns into a damnable kind of abuse of power (Epistula 93.2-3)

Finally, after 411 Augustine primarily manifested himself as a mystagogue, whose aim was to accompany people as a coach in the transformation that results from their relationship with God, and as a theoretician of mystagogy. Ironically it is his Epistula 185, the letter in which he recorded his view on the use of compulsion and coercion, in which he presented himself as a mystagogue. He points out that laws, compulsion, and coercion are justified only if their purpose is to establish unity and brotherly love (Epistula 185.7.25). ${ }^{8}$ The laws serve to heighten fear, but as such they are 'merely' the prelude to reflection and growth in the faith (Epistula 185.2.8). He expressly situated compulsion and coercion at the beginning of an individual and collective process of formation, thus showing a mystagogical rather than a pedagogical approach. He emphasised that laws that are experienced as coercive must in the church be seen exclusively as the prelude to formation with a view to unity. He regarded this unity as the principle of people's happiness (Epistula 185.6.23).

Augustine's attitude to non-Catholic Christian factions is thus expressly marked by his concern for the restoration of unity, which he believes is guaranteed in the Catholic Church as the body of Christ. Initially, he considers dialogue to be the most appropriate means of restoring this unity. But if it proves unavailing, he does not hesitate to justify state coercion on behalf of this unity, and, through sharp interrogations, to confront his adversaries with what he believes are their fruitless vision and practice. But hard confrontations are the first beginnings of a process of purification and formation, which Augustine views through the eyes of the mystagogue rather than of the judge. The church as an organism and as the body of Christ experiences healing in the process. When Augustine says in Retractationes 2.5 that he never approved of compelling schismatics to return through pressure from the civil authorities, this is therefore no dissimulation, even though paradoxically he did justify coercion and intervention by the state.

8 Unlike in 402, he calls the Donatists heretics again at this point. 
Augustine's Relations with Specific Heretics: A Common Thread and a Snapshot

In addition to these stages in his development, it is possible to identify a common thread in and an interesting snapshot of Augustine's attitude towards the heretics. ${ }^{9}$ Around 392, he wrote as a young priest in Enarratio in Psalmum 9 that God does not want heresy, but that he permits it. Just as the darkness renders the light enjoyable, so comparison with heresy makes the discovery of the truth all the more pleasing (Enarratio in Psalmum 9.20). ${ }^{10}$ Shadow and evil are useful to the extent that they contribute to the awareness that the light and the good are preferable. In this way, heterodoxies are also part of God's order. The comparison (comparatio) between orthodox and heterodox views contributes to the discovery of the truth, which is rather exclusively confined within the former (Enarratio in Psalmum 9.20). The usefulness (utilitas), perhaps the necessity, of these movements is situated therefore in their contrast effect.

Augustine is indebted here to the Stoic notion that good people are tested, repelled, exhorted, or corrected by unpleasant things. Seneca argued that evil is useful because it causes the good to correct themselves. Moral evil therefore has its own place in the order, and even serves it. For Plotinus, too, evil people serve ad utilitatem sanctorum (Bouton-Touboulic 2004, 438-39, 447, 452-6o). It is not unlikely that the young Augustine had learned this principle of contrast during his formation as a rhetor, making him inclined later, once he had become familiar with Scripture and tradition, to agree with Tertullian's interpretation of 1 Cor. 11:19. Paul writes in the letter to the Corinthians that it is necessary that there should be different factions among the Christians, so that those who can be trusted should be clearly recognised. Because the Latin translation that Tertullian had at his disposal, used the term 'heresies' for Paul's factions, he interpreted these as heresies- the heresies thus made the Catholic faith all the more clearly recognisable. ${ }^{11}$ The older Augustine followed him in this argument. This is clear from De ciuitate Dei 16.2, where he repeats his conviction already formulated in Enarratio in Psalmum 9 and where he also refers to 1 Cor. 11:19. Like Tertullian, he also uses the word haereses rather than factions, and he adds that the Catholic faith is manifested all the more clearly through the contrast effect of the teachings of the heretics (De ciuitate Dei 16.2).

9 Cf. Wurst 2010, 298, who briefly also mentions De Ciuitate Dei 18.51: "deus utitur et malis bene" (18.51).

10 Enarratio in Psalmum 9. 20: "Quo mysterio agitur ut etiam haereses esse permittantur ... diuina ... prouidentia.... tenebras autem ordinat, ut sit earum comparatione lux gratior, sicut haereticorum comparatione iucundior est inuentio ueritatis".

Tertullian, De Praescriptione Haereticorum 4, 6; See also Confessiones 7.19.25. 
It is true that in De ciuitate Dei 16.2 he clearly states that heretics are characterized by a spirit of impatience and unruliness and disrupting the peace of the saints. But here too he places this in the light of 1 Cor. 11:19. Heresies are useful for those who make progress and the orthodox are tested by them. Augustine is not so far from Origenes' thought that heresies can act as a catalyst for orthodox thinking (Ledegang 2016).

Around 418-420 Augustine delivered his Sermo 117. It is an 'attack' on the Arians. This Sermo contains a snapshot, outlining a rather exceptional perspective on the treatment of heretics (Van Geest 2011)..$^{2}$ In his early period, Augustine had been very critical of anthropomorphic conceptions of God in North African and Catholic popular culture. According to him, these obstructed the realisation that God is first and foremost a mystery, and not a supreme being with the same physical features and emotions as human beings. In sermo 117 he raised the same point again. The Arians contended that God the Father must precede the Son in time, so that the Son cannot be equal to the Father. Augustine seems to be convinced: he even drops the word 'anathematur'. He also says that their thoughts make that they do not belong to the "societatem sanctorum" (Sermo 117.4.6). He thought that this approach failed to do justice to the incomprehensibility and ineffability of God, because it is too strongly premised on natural conditions on earth. According to him, the Arians' image of God was much too human, and this meant that just like the simpliciores, they failed to do justice to God as a mystery. His criticism of 'heretics' is essentially the same as his criticism of those who held a popular, anthropomorphic image of God. Their representation of God is too physical.

At the same time, Augustine praises the Arians in Sermo 117 because they clearly manifest that the Father and the Son are of the same nature. He also begins the sermon with the insight that Catholics and Arians are best advised to be silent before God rather than to speak about him, precisely because God is a mystery. This unifying statement contributes to a much milder tone than what might be expected of a sermon preached for the confounding of heresies. It is true that Augustine denounces the Arian notion that Christ was not equal to the Creator. But at the same time he argues that humans try to do the impossible if they attempt to grasp God, because they are seeking someone who is unknowable and ineffable (Sermo 117.2.3). Augustine consequently comments that John 1:1-3, the subject of his sermon, was not written to be understood, but to confront readers with the inadequacy of their minds, so as to tempt them to adopt the required humility which can engender longing for God

12 In Sermo 117, Augustine is much less indebted to an 'us' vs. 'them' framework than Gregory of Nyssa is in his works against the Arians (Leemans 2011). 
(Sermo 117.3.5; cf. 5.7; 5.8). Despite the fact that he criticises the Arians, it is therefore unlikely that Augustine intended to attack them in this sermon. The emphasis on God's incomprehensibility is simply too strong, even when Augustine touches on the doctrinal differences between Catholic and Arian Christians. His main objective was to prove that it is precisely orthodoxy which intensifies the awareness that God is a mystery, and that he should not be the subject of speculation but of stillness and silence (Sermo 117.5.7). ${ }^{13}$ It is true that people can understand 'in part', 'in a riddle', 'through a mirror', something about the simultaneity (coaevitas). Augustine emphasizes 'posse fieri', 'posse intellegi, ut et natus sit et coaeternus sit ei a quo natus est' (it can be done, it can be understood that he was both born and eternally of God the Father). But this does not alter the fact that straightaway in the following paragraph he revisits the idea that the relationship God-the-Father and Son is a res ineffabilis, because the similitudines are imperfect (Sermo 117.5.6; 6.9).

At the end of his life, Augustine felt the need to create an overview and a synthesis, as is evident from the fact that he composed his Retractationes, Speculum and De Haeresibus. ${ }^{14}$ The praefatio of De Haeresibus shows that he also wished to draw up a synthesis of existing heresies, as he writes that such a project would exceed his powers. We have the perseverance of the Carthaginian deacon, later bishop, Quodvultdeus to thank for the fact that De Haeresibus was eventually written (Scopello 2010: 278-290). It is clear from their correspondence and from the foreword that Augustine was always looking for excuses not to undertake this work (Epistulae 221-224; De Haeresibus, Praefatio).

Augustine's main sources were Epiphanius of Salamis's Panarion (Пavápiov, 'Medicine box'), and the summary of, and additions to this in the Anakephalaiosis, as well as Philastrius of Brescia's Diuersarum hereseon liber (Bardy 1931). ${ }^{15}$ Epiphanius is the source-sometimes copied literally-for sections 1-57; Philastrius for sections 58-80. The last line of the discussion of

\footnotetext{
13 Sermo 117. 5.7: "Et quid facimus nos? Silebimus? Utinam liceret! Forsitan enim silendo aliquid dignum de re ineffabili cogitaretur".

14 De Haeresibus has been consulted mainly in the context of research of Manichaeism, Donatism, and Priscillianism. For the work itself, see: Scopello 2010; Tasca 2010; Sadowski 2015; Müller 1956; Jannacone 1952.

15 On Celsus, an author who catalogued various philosophical movements and who was possibly Origen's adversary in Contra Celsum, see Scopello 2010, 283-284. See for the Panarion: Verheyden 2011.
} 
the Sabellians (41) shows that Augustine was a critical reader of Philastrius (De Haeresibus 41). ${ }^{16}$ He probably based his treatment of the Luciferians (81) and Jovinians (82) on an Indiculus wrongly ascribed to Jerome, and that of an Arabian heresy on Eusebius' Historia ecclesiastica (83). It is striking that Augustine does not wonder whether the heresies listed in the Panarion, Diuersarum hereseon liber and Indiculus actually existed. The fact is that he did not all experience them at first hand. However, his lengthy description of the Pelagians (88), as well as of the Manichaeans (46) and the Donatists (69) are evidently based on personal memories. Although Augustine also had personal experience of the Circumcelliones (69), his choice to designate them as "genus hominum agreste", "famosissima audacia", "immania facinora" point, however, more to indebtedness to Sallust than to his own experience (Shaw 2006).

In De Haeresibus, in what reads simultaneously like an aide-memoire and a monitio, Augustine lists the most essential ideas and practices of a total of 88 heresies that had arisen since the coming of Christ, sometimes after an explanation of their names (Scopello 2010, 286). Sydney Sadowski has distinguished eleven heresies concerning the humanity of Christ, ten that denied the divinity of Christ, and one which denied that Christ had truly died (Sadowski 2015: 475, footnotes 66-68). Seventeen heresies practiced sacramental rituals that were contrary to Catholic teaching on the sacraments; nineteen had an erroneousoften Gnostic - view of the origins of creation, the world, and the angels, and fifteen taught error on the nature of God and his relationship with creation, Christ, the Holy Spirit, and humanity. In twenty heresies, Augustine identified an eschatology that was contrary to orthodoxy; three heresies erred in relation to the interpretation of the apostolic doctrine, the activity of the Holy Spirit or of the Trinity. Three heresies concerned Mary's virginity, and thirty-three heresies, finally, can be classified on the basis of a plurality of assumptions that are contrary to the Catholic faith (Sadowski 2015: 476-477, footnotes 69-78).

It is understandable, therefore, that Augustine states in the praefatio (7) that he finds it very difficult to say "quid faciat haereticum", and in his epilogue that it is impossible to list the points in which the heretics "a ueritate dissentiunt" (epilogus 3). The fact that the second, theoretical part of De Haeresibus never materialised was partly due to this problem. Agostino Trapè nonetheless succeeded in distilling the hermeneutical, psychological, ecclesiological, and Christological criteria from Augustine's entire oeuvre which would have furnished grounds for regarding the groups mentioned in this part as heretical. He also observed that Augustine always emphasised the importance of lovingly

16 De Haeresibus 41: "Et tamen Noetianos et Sabellianos sub duobus numeris tamquam duas haereses posuit; qua causa, ipse viderit”. 
educating 'heretics' (Trapè 1985). Sadowski deduced criteria that Augustine could have mentioned in this part from the descriptions in De Haeresibus itself. Like Trapè, he concluded that Augustine regarded arrogance as the motive behind breaking away from the Catholic church and thus behind heresy, something which cannot be the result of ignorance but is done by important, erudite people ("Non fecerunt haereses nisi magni homines", Enarratio in Psalmum 126.5). Heretics think that issues which they reject are unable to provide hope of salvation, they are perseverant, and they systematically interpret the divine revelation in an erroneous way (Sadowski 2015: 470-473).

But both Sadowski and Trapè were almost exclusively interested in discovering doctrinal criteria. In a study of the eating habits (of the Nicolaites, Priscillianists, Manichaeans, Ophites, and Cataphrygians) that Augustine denounced as despicable, Francesca Tasca has demonstrated, however, that he regarded less dogmatic aspects as at least equally important (Tasca 2010). In De Haeresibus 46, for instance, he stresses the connection between heresies, physical uncleanness, and the corresponding impurity of the soul (Müller 2017: 373-375). This means that Augustine also looked at other aspects of the Christian factions that he counted among the haereses than the doctrinal one alone. This is a very important argument to use when it comes to discussing the dominance of doctrinal theology in the past. A pattern can even be identified in De Haeresibus, that points to an attempt to emphasise a profound link between orthodoxy and the good life. Augustine does not create the dualism of orthodoxy and orthopraxis.

It is striking for instance that whenever Augustine discusses a particular Christian faction more extensively, he first condemns their sexual excesses before he denounces their abject doctrines. Thus in his discussion of the $s i$ moniani (1), named after Simon the Magician (Acts 8:9-25) he fulminates first against the shameless use of women as communal property ("Docebat autem detestandam turpitudinem indifferenter utendi feminis"). Only then does he criticise Simon's denial that God has created the world and that there will be a resurrection of the body (De Haeresibus 1 ). The same sequence can be found in his treatment of the Saturnians (3). They are counted among the haeretici firstly because they propagated the shameless practices of Simon ("turpitudinem Simonianam") in Syria, and Augustine discusses their abject creation myth only subsequently. The same pattern is visible in relation to the Nicolaitae (5), named after Nikolaos who was appointed one of the seven deacons by the apostles (Acts 6:5). First he takes Nikolaos to task for offering his beautiful wife to all interested parties, thus creating a shameless sect ("sectam turpissimam") whose members, like the Simonists, regarded women as communal property ("placet usus indifferens feminarum"). He criticises their view of creation only 
subsequently. Similarly, Augustine's criticism of the Borborites, a subsect of the Gnostics (6), begins with a comment on their excessive shamelessness ("nimiam turpitudinem") in the performance of their rituals, before referring to their fanciful stories ("fabulis ... stultissimis") about God, nature, and the soul. The same pattern occurs in his treatment of the Carpocratians (7) and the Origeniani (42-43) (for Origeniani cf. Grossi 1992). When he mentions the Archontici (20), he first explains their name, then criticises their shameful practice ("quamdam turpitudinem"); and only then censures their denial of the resurrection of the body. It is true that Augustine does not explain what the "opera turpitudinis" of the Secundians (12), the Valesii (37) or the Paternians (Venustians, 85) are (for Paterniani cf. Lamberigts 1985). But as has been seen, his use of a declension of the noun 'turpitudo' in the passages on the Simonists, Saturnians, and Nicolaites points to some illicit sexual practice. It is likely therefore that Augustine had some such practice in mind here too, as he had in the case of the Priscillianists (70). In his discussion of the latter Spanish sect, his examination of their abject doctrines is once again preceded by criticism of their "contaminationes et turpitudines".

The vehemence with which Augustine denounces the turpitudines of the sects to which he devotes an extensive discussion is almost fugal. Precisely in the condemnation of aspects of lived practice De Haeresibus has striking parallels with Augustine's Speculum, which he composed around the same time. The Speculum contained guidelines from Scripture so that it would reflect the image of the person who looked into it in as detailed a fashion as possible, as if in a mirror; the confrontation with one's own imperfections had to be brutal. One wonders whether Augustine's aim in writing De Haeresibus was not the same as for the Speculum - to offer his own congregation a mirror to confront them with their own life-and whether this is not the reason that he emphasises this aspect. This would also mean that he was keen not to be a hammer of heretics, but a bishop desirous of keeping his faithful together by describing views and life practices as a deterrent, using the mechanism that would later be called scapegoating.

But Augustine not only condemns sects on the basis of their sexual excesses; he also criticises the other extreme: the abstinence that some sects impose upon their members. Again, he does this before discussing their doctrinal errors. Thus he denounces the conviction of the Tatians (Encratitae, 25) who regarded marriage as fornication and refused to admit anyone who was married. Similarly Augustine condemns the views of the Cataphrygians (26) and the Tertullianists (86) who regarded second marriages as adultery; the Adamites (31), who, imitating Adam's nakedness, rejected marriage; the Catharists (Novatians, 37) who did not permit second marriages, and the Apostolici 
(Apotactitae, 38), who declined to admit anyone who slept with a woman. He also rebukes de Abelians (Abelites, 87) for the same reason (Ackermans 2011). They did not have relations with women, but were not allowed to live without them either. They therefore adopted children while taking vows of sexual abstinence. Augustine clearly also views this option as sectarian and unnatural. He condemns the Hieracites (47) who admitted only monks, nuns, and unmarried people; the Aerians (53), who, like the Encratites and Apotactites, admitted only people who practiced abstinence, and the Priscillianistae (70.2), who tried to separate married men and women because the genesis of any kind of flesh must be ascribed to evil angels. He also rejects the Manichaean avoidance of procreation. Their idea that the divine substance is entrapped in children and therefore becomes woefully divided failed to win his approval $(46.6 ; 46.13)$.

However, Augustine was certainly not the only one to express his rejection of radical asceticism on the one hand and radical body glorification on the other. He is simply following the long-standing conventions of early Christian heresiology (Gorce 1953; Hunt 2016: 47-62,114-115, 125-136, 159-183). But his almost literal indebtedness to the table of contents that precedes the description of every heresy in Philastrius' Anakephalaiosis, does not detract from the fact that, in De Haeresibus, Augustine is intent on finding a middle ground between sexual excesses and abstinence. It is evident from De Haeresibus that he, more than the Encratites, Gnostics, and other kinds of heretics, aspires to a life of moderation in sexual practice and a rejection of exaggerated and excessive forms life in which the care of the body is neglected, as can be deduced from his discussion of the Valesians (37), whose custom was to castrate their guests, or of the Catharists, who were reluctant even to eat plants because there is life in plants (46.11). His pursuit of balance is also evident from his condemnation of the Euchites ( 57 Massalians), a verdict which he had already explained at length in De opere monachorum in 40o. The Euchites only wanted to pray; and according to Augustine they did too much of this: "Nimis hoc faciunt". His criticism is the same as that of the Euchite monks that he had criticised around 400 in De opere monachorum because they wanted to pray and refused to do anything to support themselves. He predicted that a life that had no variation between spiritual and physical work would disturb humans' inner balance. He rejected an excessively rigid prayer life (De opere monachorum, 17.20). It transpires in De Haeresibus that he thought such a life was not orthodox either.

A very global comparison with the sources shows that Augustine has distilled precisely those passages from his sources, which enabled him to emphasize the connection between orthodoxy and orthopraxis. In the light of his objective, it is also possible to explain why he does not dispute views that have to do with, for example, the divinity of the intellect, or theurgy. This was not 
discussed in De Haeresibus, whereas he wants to see theurgy and demonology heavily punished in De ciuitate Dei. In De Haeresibus he explicitly wants to reduce the wrong way of life to an erroneous idea of God or to the erroneous conception of man; for example, one in which man is not held responsible for his own actions.

\section{5}

\section{Conclusion}

In 1934, in Rechtgläubigkeit und Ketzerei im ältesten Christentum, Walter Bauer remarked that in many areas a 'heresy' was the first form of Christianity (Bauer 1964). Although Turner contested this with good counter arguments, he also noted that, in all its changeability, thinking about human beings and God in the first century resembled a symphony more than a monophonic melody; the confluence of several rivulets into a single stream more than a river that seeks its way to sea without mixing with other streams (Turner 1978: 9).

Many centuries before, Irenaeus contended that the first rule of the faith was accepted by everyone everywhere (Irenaeus, Adversus Haereses I, book X, par. 1.2). Historically speaking this is not correct. He implied a unity among pluralistic Christians that did not initially exist. The unity of Christendom had been realised to a much greater extent by Augustine's time. But Christianity was still a plurality, as the splits—-such as that of the Donatists—or original diversity — such as the Simonists and Nikolaites—show. This is evident even from De Haeresibus alone. Even though he bases himself on sources and is likely that he never experienced these currents personally-it is even questionable whether they all really existed - Augustine evidently wants to explain the pluriformity and polycentricism of Christianity from its very beginnings, giving explicit consideration to the fact that unequal distribution of power has influenced the dynamics between orthodoxy and heterodox 'centres'. In a certain way he wants to demonstrate that in his time Christianity had failed to produce a united and univocal church with a unified theology, practice, and liturgy, despite the exertions of emperors, councils, church fathers, bishops, and popes. Nonetheless: this does not alter the fact that Augustine regarded the Catholic Church, with the bishop of Rome as the most authoritative guardian of the church's unity and wholeness, as the Body of Christ. He condemned the Donatist church for this reason. As early as 391, Augustine considered the Donatist church to be too regionally oriented to be able to safeguard the unity of the universal church. His rejection in his denunciation of Donatism of the normativity of interpretations of tradition that are too strongly rooted in one 
particular context can be traced back to his vision of the Catholic church as the guardian of unity and truth.

Augustine lived in a violent time characterised by a strongly agonistic culture. Competitive disputes were fought out in courtrooms, arenas, or circuses between skilled orators who used all kinds of rhetorical devices (Humfress 2012: $323-324,328)$. Given this context it is all the more remarkable that Augustine initially stressed dialogue to regain the Donatists for the Catholic Church. He drew up a number of rules for this. But as soon as this remedy proved ineffective, he did not hesitate to justify coercion by the state to achieve unity, and to employ the rhetoric of persuasion in sharp interrogation. Assisted by imperial force, he quickly abandoned this road to develop a formation process for Donatists who had returned, a process in which fear of coercion is ideally embedded in love for the unity of the church. This love is ideally aroused by the benevolence, sympathy, and love of the Catholics who coached them. But the violence that Catholics used against returning Donatists proves that this was far from being universal practice - to Augustine's great regret (Sermo Casinensi I. 33). ${ }^{17}$ With regard to the Donatists, he deeply believes in dialogue, but from the conviction that the 'catholicity' is based on the universality and originality preserved and passed on in his pars catholica.

The common thread in his attitude to heretics, which he articulated in Enarratio in Psalmum 9 and De ciuitate Dei 16.2 shows that Augustine, like Irenaeus, espoused the historically inaccurate idea that orthodoxy had been under threat from the very beginning of Christianity by a plurality of heresies. He nevertheless formulated the value of heresies very explicitly in these texts. The comparison (comparatio) of orthodox and heterodox tenets contributes to the discovery of the truth of the former. The utility (utilitas), perhaps the necessity, of these factions is therefore situated in the fact that they highlight the contrast. And in Sermo 117, which is more a snapshot than anything else, he even went so far as to say something positive about the Arians because they professed that the Father and the Son were of the same nature. He looked for some kind of common ground, possibly because the Arians had ceased to be much of a threat to the unity of the church. Orthodox and heterodox Christians were both best advised to be silent about God rather than to speak about him. But at the same time he suggests that heresies are characterized by a lack of hermeneutics.

17 Cf. Sermo Casinensi I. 33, in: Sancti Augustini Sermones Post Maurinos Repertos. Ed. G. Morin (Roma, 1930), 401-412, quote: 410-411. 
It is very clear from De Haeresibus that Augustine generally reasoned in an absolutist way, as was the custom in Antiquity. This work demonstrates that he was an exponent of the Christians who believed that there were only right and wrong answers to the question whether Jesus Christ revealed the good Creator, and whether God truly came to humankind in Christ. Criteria of truth—such as apostolicity - were developed in the heresiologies and dogmatic florilegia of the third, fourth and fifth centuries that could be used to take the measure of alleged heretics. These criteria already underlie De Haeresibus, albeit implicitly. It can also be observed that Augustine used rhetorical techniquesexclamations and rhetorical questions - that form a prelude to strong language against the heretics (Cameron 2012: 7-10).

But De Haeresibus is more than just a heresiology. Precisely because doctrine follows the description and condemnation of aspects of life praxis, $D e$ Haeresibus shows remarkable parallels with Augustine's Speculum, which, like a mirror, reflected as detailed and unpolished an image as possible of the person who looked into it, thus making a confrontation with one's own imperfections unavoidable. Practices are also listed in De Haeresibus that would have been suitable material for the Speculum. Even though he is simply following the long-standing conventions of early Christian heresiology, Augustine thought in De Haeresibus that orthodoxy and a balanced and good life are connected. He also condemned Encratite and Gnostic movements in the first place because the lifestyle they practiced did not foster care of the body, a balanced sexual life, inner equilibrium, or moderation. Augustine's attention to praxis in addition to the doctrine shows that representations of Christianity in the past as purely concerned with doctrine must be corrected.

The welcome news that orthodoxy, moderation, equilibrium, and the good life are even more interconnected in De Haeresibus than is evident at first sight does not, however, absolve us from the duty of reconstructing the doctrines of the various heresies as meticulously as possible. Only then will it be possible to determine whether the struggle against heresy was indeed fair and equitable. Or did Augustine perhaps exaggerate the turpitudines and abstinence which

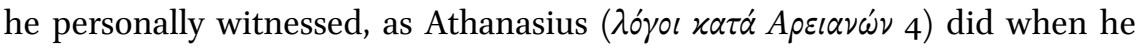
called Arius voluptuous? Perhaps it was convenient to describe the heretics in the bleakest of terms in order to make the mirror more effective? And should the Catharists really be condemned on account of their respect for vegetable life? In their recent Verde brillante. Sensibilità e intelligenzia del mondo vegetale, the neurobiologists Stefano Mancuso and Alessandra Viola argue that it is ethically more responsible to eat plants than animals, because approximately 1600 kilos of plant are necessary for one kilo of meat. Does this not mean that Augustine's perspective is obsolete? 
It is difficult to answer such questions. We do not even have fragments of the texts that circulated in the many sectae. The plurality of Christianity is nonetheless incontrovertibly clear in Augustine's De Haeresibus. The fact that this church father condemned moral excesses makes him a precursor not only of theologians, but also of psychologists - as is also true for the Confessiones and their invitation to introspection. For Augustine, confounding heretics and propagating a balanced and serene life are harmoniously linked together; they are even inseparably linked.

\section{Bibliography}

Ackermans, Gian (2011). 'Einige Rechtliche und Theologische Fragen zu den Abeloitae in Augustins De Haeresibus.' In Jacob Albert van den Berg, Annemaré Kotzé, Tobias Nicklas and Madeleine Scopello, eds. In Search of Truth. Augustine, Manichaeism and Other Gnosticism. Studies for Johannes van Oort at Sixty. Leiden: Brill: 123-138.

Augustinus, Aurelius (1930), Sancti Augustini Sermones post Maurinos reperti. Edited by Germani Morin. Rome: Typ. Polyglottis Vaticanis.

Bardy, Gustave (1931). 'Le De Haeresibus et Ses Sources.' Miscellanea Agostiniana II: 397-416.

Bauer, Walter (1964). Rechtgläubigkeit und Ketzerei im ältesten Christentum. Tübingen: Mohr (translation: Orthodoxy and Heresy in Earliest Christianity. Philadelphia: Fortress Press, 1971).

Bouton-Touboulic, Anne-Isabelle (2004). L'Ordre Caché. La Notion de l'Ordre Chez Saint Augustin. Paris: Brepols Publishers.

Brown, Brian, John A. Doody and Kim Paffenroth (2008). 'Introduction.' In Brian Brown, John A. Doody and Kim Paffenroth, eds. Augustine and World Religions. Lanham: Lexington Books: vii-xii.

Cameron, Averil (2012). The Cost of Orthodoxy. Leiden: Brill.

Dekker, Eloi and Jean Fraipont, eds (1990). Enarrationes in Psalmos LI-C (2nd edition). Brepols: Turnhout.

Drecoll, Volker H. (2001). 'Etiam posteris aliquid profuturum. Zur Selbststilisierung bei Augustin und der Beeinflussung der eigenen Wirkungsgeschichte durch Bücher und Bibliothek', Revue des Etudes Augustiniennes 47: 313-335.

Geest, Paul van (2011). The Incomprehensibility of God. Augustine as a Negative Theologian. Leuven: Peeters.

Geest, Paul van (2014). 'Quid dicam de vindicando vel non vindicando? (ep. 95.3). Augustine's Legitimation of Coercion in the Light of his Role of Mediator, Judge, Teacher and Mystagogue.' In Albert Geljon and Riemer Roukema, eds. Violence in Ancient Christianity. Victims and Perpetrators. Leiden: Brill: 151-184. 
Geest, Paul van (2015). 'Timor est servus caritatis (s. 156.13-14). Augustine's Vision on Coercion in the Process of Returning Heretics to the Catholic Church and his Underlying Principles.' In Anthony Dupont, Matthew Allan Gaumer and Mathijs Lamberigts, eds. The Uniquely African Controversy. Studies on Donatist Christianity. Leuven: Peeters: $289-309$.

Geest, Paul van (2017). 'Sed ea quae obscura sunt praetermitto' (Speculum 108). Augustine' Selection of Scriptural Quotations as Proof of his Desire to effect a Confrontation', Rivista Augustinianum 57: 511-532.

Geest, Paul van (2018). 'The Authenticity of Augustine's Speculum and an Unknown Reason for the Compilation of this Treatise.' In Andreas Gottsmann, Pierantonio Piatti, Andreas Rehberg, eds. Miscellanea in Occasione del 70 Genetliaco di Mons. Sergio Pagano, Prefetto dell'Archivio Segreto Vaticano. Città del Vaticano, Archivio Segreto Vatican.

Jannacone, Silvia (1952). La Dottrina Eresiologia di S. Agostino. Catania: Università, Centro di studi di letteratura cristiani antica.

Gorce, Denys (1953). 'Corps (spiritualité et hygiène), In: Dictionnaire de Spiritualité 2. Paris: Beauchesne: 2338-2353.

Grossi, Vittorino (1992). 'La presenza di Origene nell'ultimo Agostino (426-430).' In

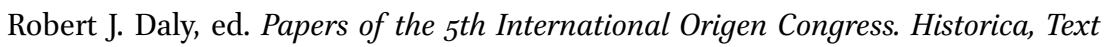
and Method, Biblica, Philosophica, Theologica, Origenism, and Later Developments. Leuven: Peeters: $55^{8-564 .}$

Humfress, Caroline (2012). 'Controversialist. Augustine in Combat.' In Mark Vessey, ed. A Companion to Augustine. Malden, MA: Wiley-Blackwell: 323-335.

Hunt, Hannah, Clothed in the Body. Asceticism, the Body and the Spiritual in the Late Antique Era. London-New York: Routledge, 2016.

Kaufhold, Hubert (2011). 'Häresie, Schisma und Apostasie in den Kirchenrechtsquellen der Orientalischen Kirchen.' In Joseph Verheyden and Herman Teule eds. Heretics and Heresies in the Ancient Church and in Eastern Christianity. Studies in Honour of Adelbert Davids. Leuven: Peeters: 313-332.

Lamberigts, Mathias (1985). 'A Short Note on the Paterniani', Revue des Etudes Augustiniennes 31,3-4: 270-274.

Lancel, Serge and James Alexander (1999a). 'Donatistae.' In Cornelius Mayer et al. eds. Augustinuslexikon 2, Basel: Schwabe: 6o6-638.

Lancel, Serge (1999b). Saint Augustin. Paris: Fayard.

Ledegang, Freddy (2011). 'The Ophites and the "Ophite" Diagram in Celsus and Origen.' In Joseph Verheyden and Herman Teule, eds. Heretics and Heresies in the Ancient Church and in Eastern Christianity. Studies in Honour of Adelbert Davids. Leuven: Peeters: $5^{1-83}$.

Ledegang, Freddy (2016). 'De Antignostische Polemiek van Origenes.' In Abraham P. Bos, Gerard P. Luttikhuizen, eds. Waar Haalden de Gnostici hun Wijsheid Vandaan? Over 
Bronnen, de Doelgroep en de Tegenstanders van de Gnostische Beweging. Budel: Damon: 117-137.

Leemans, Johan (2011). 'Preaching and the Arian Controversy. Orthodoxy and Heresy in Gregory of Nyssa's Sermons.' In Joseph Verheyden and Herman Teule, eds. Heretics and Heresies in the Ancient Church and in Eastern Christianity. Studies in Honour of Adelbert Davids. Leuven: Peeters: 127-142.

Migne, Jacques Paul ed. (1844). Patrologia Latina 8. Paris: Migne.

Müller, Daniela (2011). 'Aspekte der Ketzerverfolgung unter den Römischen Kaisern.' In Joseph Verheyden and Herman Teule, eds. Heretics and Heresies in the Ancient Church and in Eastern Christianity. Studies in Honour of Adelbert Davids. Leuven: Peeters: $175^{-193 .}$

Müller, Daniela (2017). 'Heresy as Impurity.' In Paul van Geest, Marcel Poorthuis and Els Rose, eds. Sanctifying Texts, Transforming Rituals. Encounters in Liturgical Studies. Leiden: Brill: $366-384$.

Müller, Liguori G. (1956). The De Haeresibus of Saint Augustine. Washington DC: Catholic University of America Press.

Pollmann, Karla, Willemien Otten et al. eds (2013). The Oxford Guide of the Historical Reception of Augustine. Oxford: Oxford University Press, 3 vols.

Ponzio (200o). Vita di Cipriano. Paolino, Vita di Ambrogio. Possidio, Vita di Agostino. Introduced, translated and with a note by Manlio Simonetti. Roma: Città Nuova (3rd edition).

Pugliese, Agostino (2009).'Der hl. Augustinus als Richter. Ein Betrag zur Geschichte der "Episcopalis Audientia".' In Johannes Hellebrand, ed. Augustinus als Richter. Würzberg: Augustinus Verlag: 21-59.

Raikas, Kauko K. (1997). 'Audientia episcopalis: Problematik zwischen Staat und Kirche bei Augustin.' Augustinianum 37,2: 459-481.

Sadowski, Sydney (2015). 'A Critical Look and Evaluation of Augustine's De Haeresibus. Augustinianum 55,2: 461-478.

Scopello, Madeleine (2010). 'Haeresibus ad Quoduultdeum (De -).' In Cornelius Meyer et al. eds. Augustinus-Lexikon 3. Basel: Swabe: 278-29o.

Shaw, Brent D. (2006). 'Bad Boys. Circumcellions and Fictive Violence.' In Harold A. Drake, ed. Violence in Late Antiquity. Perception and Practices. Aldershot: Ashgate: 179-196.

Smither, Edward L. (2015). 'Augustin, Missionary to Heretics? An Appraisal of Augustine's Mission as Engagement with the Donatists.' In Anthony Dupont, Matthew Allan Gaumer and Mathijs Lamberigts, eds. The Uniquely African Controversy. Studies on Donatist Christianity. Leuven: Peeters: 269-288.

Tasca, Francesa (2010). "Ecce Panis Haereticorum”. Diversità Alimentari ed Identità Religiose nel “De Haeresibus” di Agostino.' Augustinianum 50,1: 233-253. 
Trapè, Augostino (1985). 'Un Libro Sulla Nozione di Eresia mai scritto da Sant' Agostino.' Augustinianum 25, 3: 853-865.

Turner, Henry E.W. (1978). The Pattern of Christian Truth. A Study in the Relations between Orthodoxy and Heresy in the Early Church. London: A.R. Mowbray.

Verheyden, Joseph (2011). 'Epiphanius of Salamis on Beasts and Heretics. Some Introductory Comments.' In Joseph Verheyden and Herman Teule, eds. Heretics and Heresies in the Ancient Church and in Eastern Christianity. Studies in Honour of Adelbert Davids. Leuven: Peeters: 143-173.

Wurst, Gregor (2010). 'Haeresis, Haeretici.' In Cornelius Mayer et al. Augustinus-Lexikon 3. Basel: Schwabe: $290-302$. 